Nama : Muhammad Muhaimin Nasrowi

Nim : 90100118044

\title{
Konsep Ekonomi Merkantilisme
}

Merkantilisme adalah suatu aliran/filsafat ekonomi yang tumbuh dan berkembang dengan pesat pada abad XVI s.d. XVIII di Eropa Barat. Ide pokok Merkantilisme adalah sebagai berikut:

a. Suatu Negara / Raja akan kaya/makmur dan kuat bila ekspor lebih besar daripada impor

b. Surplus yang diperoleh dari selisih atau ekspor neto yang positif tersebut diselesaikan dengan pemasukan logam mulia, terutama emas dan perak dari luar negeri. Dengan demikian, semakin besar ekspor neto, maka akan semakin banyak yang dimiliki atau diperoleh dari luar negeri.

c. Pada waktu itu logam mulia (emas maupun perak) digunakan seabgai alat pembayaran (uang), sehingga Negara/raja yang memiliki LM yang banyak akan kaya/makmur dan kuat.

d. Logam Mulia yang banyak tersebut digunakan oleh raja untuk membiayai armada perang guna memperluas perdagangan luar negeri ini diikuti dengan kolonialisasi di Amerika Latin, Afrika, dan Asia terutama dari abad XVI s.d. XVIII.

Menurut David Hume ide atau pokok pikiran dari merkantilisme mengatakan bahwa Negara/raja akan kaya/makmur bila $\mathrm{X}>\mathrm{M}$, sehingga Logam mulia yang dimiliki akan semakin banyak. Dengan kata lain, kekayaan/kemakmuran suatu Negara/raja identik dengan jumlah logam mulia yang dimilikinya. Logam mulia pada waktu itu digunakan sebagai alat pembayaran/uang sehingga bila logam mulia banyak, maka ini berarti Money Supply. 
Pada awalnya, merkantilisme dirancang terutama untuk kepentingan negara yang menggunakan kaum saudagar sebagai ujung tombaknya untuk mencari kekayaan sebesar-sebesarnya, mereka berpandangan bahwa bahwa apabila suatu negara meningkat kekayaannya maka akan meningkat kekuasaannya baik dalam negeri maupun di dunia internasional, dan mereka percaya bahwa teori merkantilis ini murapakan perpaduan yang sempurna antara sistem ekonomi dan politik.

Di masa merkantilisme, pada umumnya Negara-negara yang melakukan perdagangan sebagai kekuatan ekonominya menghendaki neraca perdagangan yang lebih baik dalam arti lebih besar nilai ekspornya dibandingkan dengan nilai impornya atau surplus dalam perdagangannya. Untuk mencapai tujuan tersebut banyak negara menggunakan cara yang dapat menekan impor seperti kebijakan tarif dan pengawasan impor. Kebijakan tarif dan pengawasan impor merupakan kegiatan yang sudah dipikirkan atau sudah dianalisis secara matang yang mengarah pada upaya peningkatan ekonomi negara tersebut. Dengan demikian, analisis ekonomi dalam melaksanakan perdagangan mulai diterapkan oleh kaum merkantilis tersebut. Karena itu, kaum merkantilis dianggap sebagai orang-orang pertama yang melakukan kajian dan analisis ekonomi secara baik.

Tokoh-tokoh Pemikir Paham Merkantilisme

1. Jean Bodin (1530-1596) Jean Bodin lahir di Angers, Prancis pada 1530 kemudian wafat di Laon pada 1596. Bodin merupakan seorang filsuf politik Prancis yang sangat mentereng di Eropa pada abad pertengahan dengan pemikirannya terkait konsep kedaulatan hukum dan politik.

2. Thomas Mun (1571-1641) Thomas Mun merupakan seorang saudagar yang berasal dari Inggris yang banyak menulis terkait permasalahan perdagangan luar negeri. Mun dilahirkan di London, Inggris. 
Kakeknya merupakan seseorang yang bekerja pada percetakan uang kerajaan dan ayahnya merupakan pedagang tekstil.

3. Jean Baptiste Colbert (1619-1683) Colbert lahir di Reims, Prancis pada 1619. Colbert bukanlah seorang ahli ekonomi melainkan dia menjabat sebagai menteri utama bidang ekonomi dan keuangan pada masa Louis XIV. Dia memperoleh penghormatan yan tinggi atas kerja kerasnya dalam menghemat anggaran kerajaan dan karyanya dalam memperbaiki kondisi manufaktur serta membawa Prancis dari dari ambang kebangkrutan

4. Sir William Petty (1623-1687) Sir William Petty lahir pada tanggal 26 Mei 1623 kemudian wafat pada tahun 1687. Dia merupakan seorang ekonom, ilmuwan dan filsuf Inggris, anggota Parlemen Inggris dan juga merupakan anggota piagam Royal Society. Teorinya banyak membahas mengenai ekonomi dan metode aritmatika politik, dan kaitannya dengan filosofi "laissezfaire" dalam relevansinya terkait aktivitas pemerintah. 
Daftar Pustaka

Wahab, A. (2013). Ekonomi Internasional.

Nasution, A. P. (2014). Kaum Saudagar Dalam Lingkaran Kekuasaan Negara. BENING, 1(2)

Amir, A. (2015). Ekonomi dan Keuangan Islam.

Ubaid Al Faruq dan Edi Mulyanto, "Sejarah Teori-Teori Ekonomi.", Modul Pembelajaran Universitas Pamulang, 2017 